\title{
Antidumping, Exchange Rate and Strategic Price Competition by Staged Game
}

\author{
Hsiang-Hsi Liu ${ }^{*}$, Teng-Kun Wang2 \\ ${ }^{1}$ Graduate Institute of International Business, National Taipei University, New Taipei City, Taiwan \\ ${ }^{2}$ Graduate Institute of International Economics, National Chung-cheng University, Chiayi, Taiwan \\ Email: hsiang@mail.ntpu.edu.tw, timwang@ccu.edu.tw
}

Received 10 January 2014; revised 10 February 2014; accepted 17 February 2014

Copyright (C) 2014 by authors and Scientific Research Publishing Inc.

This work is licensed under the Creative Commons Attribution International License (CC BY).

http://creativecommons.org/licenses/by/4.0/

(c) (i) Open Access

\begin{abstract}
When the dumpers have certain monopoly power to separate the domestic and foreign markets efficiently, and consider the higher elasticity of demand in foreign markets, the firms will sell the like products at lower prices in foreign markets for increasing market shares. In this study, the analysis from antidumping was provided to demonstrate the decision made by dumping behavior. Dumping is traditionally defined as a discriminating behavior of international prices. From the trade sphere, exchange rate plays an important role on evaluating "LTFV" (less than fair value) to cause the domestic industry to suffer "material injury". Moreover, this article also discusses the equilibrium whether antidumping law exists or not under the consideration of profit maximization. A staged game is applied to analyzing the players' behaviors and to influencing the decisions of government trade policies.
\end{abstract}

\section{Keywords}

Antidumping, Staged Game, Exchange Rate, Price Competition

\section{Introduction}

This study contributes to antidumping (AD) discussed by exploring the real trade phenomena from the regulation of the GATT/WTO. The AD determination from theoretical viewpoints will be influenced by the AD filing procedure. Through various definitions of dumping and other issues of trade protection, the domestic government will consider the optimal strategy to solve the unfair trading problems without hurting the local industries, and also at same time without disturbing the trade harmony with foreign countries. Under perfect competition in all markets, it is well known that the optimal trade policy of a small country is free trade, while a large country benefits from imposing a positive import tariff. This article constructs a price-competitive duopolistic model to ana- 
lyze the behavior of firms on AD law, and to derive an optimal tariff on social welfare by considering the exchange rate endogenously decided by the price.

Moreover, this study discusses the AD decisions from a staged game to stress the determinants of trade policies, which are specifically affected by the domestic government decisions. The significance of AD regulation is measured by both economic consideration and national welfare. The conclusions will carefully contrast results from previous studies. The objective of this research is to throw new light on the following questions:

1) If the exchange rates were endogenously decided, would the import tariff be good for the home country's social welfare in the equilibrium of imperfect competition without $\mathrm{AD}$ law?

2) If the model is simplified so that two firms sell the like products and compete in prices, then a two-period duopoly model can be created in order to maximize the profit by considering whether or not AD duty is good for home country's social welfare?

The reminders of this study are organized as follows. A brief literature review is presented in Section 2. In Section 3, a model is described and set out to determine the effects on the government's announcement of the optimal trade policy without AD law. The model is then extended further to allow for the possibility of AD law. Section 4 contains concluding remarks and possible extensions.

\section{Literature Review}

Under the conditions of imperfect competition, asymmetric information, or incomplete capital market, the aim of dumping strategies for foreign companies with low pricesare probably to destroy and drive the competitors out of the market (Matschke and Schöttner (2009) [1], Pierce (2011) [2]). Early studies on predatory dumping were mentioned by Viner (1966) [3], Herander (1984) [4] and Hartigan (1994) [5] while Ethier (1982) [6] brought up the theory of cyclical dumping, i.e. that if a product demand of future market is uncertain, or the domestic economy is in recession, it could be dumped to the foreign market with low prices, which might be lower than the cost. Hillman and Katz (1986) [7] also showed that when the demand of the domestic market is uncertain with overproduction, firms may dump their products to foreign market with price lower than the marginal cost.

Dixit (1988) [8] examined imperfect competition and constructed a conjectural variations model of oligopoly. The firms choose quantities to maximize profits non-cooperatively, but they are interested in conjecturing about each other responses. He thought that foreign export subsidies and dumping can construct an aggregate real income gain to the importing country by improving its terms of trade, but it would actually hurt the domestic import-competitive industries. Therefore, he suggested that it is better to compensate them by income redistribution rather than protect them by setting trade restrictions. Brander and Krugman (1983) [9] pointed out that when a market has imperfect competition and that transportation cost exists, if the foreign market has a higher elasticity of demand. Then it will cause foreign prices to be lower than domestic prices, this explains why reciprocal dumping is observed when two countries undergo bilateral trade. What kind of influence will be affected by the dumping behavior from exporting countries to domestic industries? In the past, most economists thought that importing countries had no reason to adopt antidumping policies, other than under pernicious dumping (such as predatory dumping). Bernhofen (1995) [10] extended Brander and Krugman's (1983) [9] reciprocal dumping model to analyze price dumping in intermediate goods by introducing a vertical industry into the intra-industry trade model without considering transportation costs. This is the central role in Brander and Krugman's model. Why abandons this assumption? He thinks that the cost of internal transportation is sometimes higher than the external one by the analysis of cross-country transportation. For example, the US importing some steel materials by sea from Asia maybe cheaper than importing from Canada by land.

Webb (1992) [11] adopted Brander and Spencer’s (1985) [12] duopoly model to challenge traditional theories. He assumed that there are two countries in the model and that they both produce the homogeneous goods with one firm selling in domestic market and the other in the foreign market. However, the foreign firm can sell in both domestic and foreign markets, whereas the domestic firm can only sell in the local market. If the conjecture variable is quantity, and the process is Cournot competition, Webb found that the result of levying an antidumping duty reduces the volume of imports and increases the domestic production and profit by industrial protectionist effects. Bian and Gaudet (1997) [13] discussed the Webb (1992) [11] model and further considered the product differentiation of domestic and foreign countries. They proved that levying an antidumping duty does not necessarily lead to an increase in the domestic price, which depends on the elasticity degree of substitution. They concluded similarly to Webb's assumption, which described the filing of $\mathrm{AD}$ if it protects the up-stream 
firms, but it is uncertain if it will hurt the benefits of the consumers and down-stream firms.

Wares (1977) [14] thought that dumping could be the lagged reaction of export prices, which reacts to the variation of the exchange rate. Knetterand Prusa (2003) [15] examined the relationships between antidumping filings and macroeconomic factors. They found that real exchange rates and domestic real GDP growth both have statistically significant impacts on AD filings. Empirically, Goldberg and Knetter (1997) [16] also concluded that approximately half of the movement in the real exchange rate is offset by destination-specific price adjustment. These results provide the initiation behind the conjecture that exchange rate fluctuations have an ambiguous effect on AD filings.

The dumping literature distinguishes between price dumping and cost dumping. Price dumping happens if the sale price charge in the imported-country market is lower than in the exported-country market, and this behavior forms a kind of price discrimination. Cost dumping occurs when a foreign firm sells its products in the imported-country market below its average total costs. The purpose of cost dumping is to capture the overseas market share, and to interrupt international competition.

Nevertheless, according to the current national antidumping regulation, when the imported countries identify the causal relationship of dumping with domestic injury, most of the cases only think about the domestic industrial profit and sacrifice the benefit of consumer and down-stream firms (Wang, 2004) [17]. Therefore, during the negotiation period of Uruguay Round, no matter what it is suggested by the countries traditionally using AD or export-oriented, under the consideration of "public benefit" or "national benefit" WTO enacted the antidumping regulation. Marsh (1998) [18] investigated U.S. firms and found that antidumping statutes are effective at improving the performance of domestic industries. This explains why trade laws can become a potentially important tool for domestic industries in creating barriers for foreign competitors, and results suggest that antidumping laws significantly increase the profits of U.S. firms that pursue antidumping protection. Therefore, under the "benefit" consideration, more and more countries enact and apply antidumping laws to protect their domestic industries. Konings and Vandenbussche (2002) [19] further empirically tested the effects of Anti-Dumping (AD) protection on the price-cost margin of firms by using a panel data set of $1666 \mathrm{EU}$ producers that were involved in AD cases initiated in 1996. Their findings indicated that price-cost margins in most cases significantly increase in the period of protection compared to a period before protection. AD policy raises market power between $3 \%$ and $15 \%$, depending on the sectors. The findings were also consistent with recent theoretical models that deal with the economic effects on price behavior in response to AD protection.

Matschke and Schöttner (2009) [1] investigated the domestic government's antidumping duty choice in an asymmetric information framework where the foreign firm's cost is observed by the domestic firm, but not by the government. The results showed that the antidumping framework within GATT/WTO may not only offer the means to pursue strategic trade policy disguised as fair trade policy, but may also help to overcome the informational problems with regard to determining the optimal strategic trade policy for domestic industries. Pierce (2011) [2] tried to detect the effects of a temporary increase in antidumping duties on the behavior and performance (welfare) of U.S. manufacturers by using a dataset that includes the full population of U.S. manufacturing firms. The results showed that an apparent positive correlation between antidumping duties and traditional revenue productivity is likely misleading. Moreover, antidumping duties allow low-productivity firms to continue producing protected products, slowing the reallocation of resources from less productive to more productive uses.

Blonigen and Haynes (2002) [20] set up a model that shows that exchange rate pass-through is likely to be substantially altered when firms face antidumping (AD) duties and that optimal pass-through of AD duties may be up to 200 percent. They found that exchange rate pass-through rise dramatically after products received AD duties, with no such change for closely-related products not subject to final AD duties. This result has important implications for previous studies that have pooled AD and non-AD products. They also found that pass-through of the final AD duties is 160 percent, which is consistent with our model's predictions. Recently, Kelly (2010) [21] commented that Blonigen and Hayne's (2002) [22] calculation for pass-through of antidumping duty estimates to U.S. pricing of $200 \%$ would be required to eliminate potential antidumping duties. In fact there is no such subtraction, and a pass-through of $100 \%$ theoretically suffices to eliminate potential antidumping duties. However, Blonigen and Haynes (2010) [22] replied that while this point invalidates our theoretical explanation and empirical evidence on the magnitude of AD duty pass-through, it does not affect our original article's theory or empirical evidence on the magnitude of exchange rate pass-through, or the presence of structural breaks in both the $\mathrm{AD}$ duty and exchange-rate pass-through coefficients stemming from $\mathrm{AD}$ investigations and orders. 
Their study still think that antidumping investigations and duties have substantial impacts on exchange rate and duty pass-through about the operation of the domestic import-competitive industries.

Regarding the influence of the antidumping system on domestic industries and total national welfare, there exist different economic viewpoints between the two approaches. The economists belonging to the Neoclassical approach, like Viner (1966) [3] and Deardorff $(1987,1989)$ [23] [24], etc. think that AD policy has the effect of protecting the domestic import-competitive industries, but it would reduce the benefit of consumers or down-stream firms, so the government would balance the impact of different groups by filing AD. On the other hand, the scholars of the Strategic approach, such as Webb (1992) [11], Bian and Gaudet (1997) [13], Konings and Vandenbussche (2002) [19], Matschke and Schöttner (2009) [1], Blonigen and Haynes (2010) [20], Pierce (2011) [2] think that adopting AD measures not only protect the domestic import-competitive industries, but also bring positive effects for the consumer and firms. The difference between the two approaches depends on the assumption of return of scale and the characteristics of market competition. Overall in the Neoclassical approach, it assumes that the production function is constant return to scale with perfect competition, but on the other hand, the strategic approach makes the assumption of increasing return to scale with imperfect competition.

\section{Model Description}

This study discusses antidumping theories from real phenomena to assume that product markets are imperfectly competitive with constant return to scale, but different in each country. Brander and Spencer (1985) [12] use the theory of imperfect competition market structure to investigate the strategic trade policies, and specifically apply the duopolistic model (Cournot behavior) to explain the benefit transferring situation. However, in imperfect competition, some of the government's policies are endogenously decided. The government has an incentive to levy an antidumping duty to protect domestic industries since the foreign imports increase too much.

The model presented is as follows. The home government acts first to set the import tariff level, and then a duopoly will be set up to identify how AD regulation will affect the foreign firm's pricing decision. There are two firms: domestic and foreign, and each will produce the like products, but not identical one, which means that the trade products can substitute for one another. The domestic firm only supplies the local market while the foreign firm could export the products to satisfy the insufficiency from Webb's (1992) [11] consideration. The dumping margin, which shows the price differential between two countries is also known as the productivity difference. If the domestic government decides to levy AD duty to reduce the price gap, there are two effects on the social welfare: one is the dead weight loss from the consumer surplus, due to spending expenditure on the import-substituted goods. The other is that local government can get extra tariff revenue and protect local industries to increase their producer surplus efficiently during lower output levels.

Dumping, which seeks ultimately to gain a larger market, will therefore be influenced in terms of social welfare. However, dumping is an observed phenomenon in the real world. Historical experience tells us that governments are subject to political pressure, economic variation, social activities, and so on, to deal with AD decision (Wang, 2004) [17]. More recent trade theorists are now acknowledging that monopolistic and oligopolistic competition in markets is a common occurrence in reality. This study seeks to explain why dumping efforts might be influenced by the home government's point of view by the variation of the exchange rate and other real economic variables. Antidumping may distort the strategic trade policy outcome, but the central idea here is to protect the domestic firms from losses if the home government punishes the foreign firm by levying an antidumping duty and compensates the deadweight loss. Import tariffs can be used to practice this "Profit-shift" policy. The result of this is that strategic trade policies including tariff information will be considered in the home government objective function.

The character of actual dumping petitioners indicates that most dumping filings occurred in the intra-industry trade of nearly-homogenous goods, like steel, chemicals, commodities, etc. In contrast to Brander and Krugman's (1983) [9] model, it showed that the observed price differentials are a function of transportation costs, but, in reality, it is not plausible. Bernhofen (1995) [10] admitted that for many dumping cases in steel products, transportation costs on water are often cheaper than those over land. From this empirical research data in Taiwan, most of AD filings are from South Korea, Japan, (which belong to the Far Eastern countries), and not from other developing countries like Brazil, Mexico, (which are far from Taiwan). Therefore, transportation cost is still a critical factor for consideration. Combining these two opinions, we develop the price dumping model not just only considering transportation costs, but also by considering the efficient production cost function, which con- 
tains conveying factors that are involved in this analysis. For this reason, there exist different levels of technology, transportation costs, with marginal productivity among countries, leading to the consideration of cost factors in helping analyze the trade dumping situation.

Further analysis of the issue of antidumping was provided by Knetter and Prusa (2003) [15], who established a two-period duopolistic model to describe how the bilateral exchange rate would influence foreign firm's pricing decision and how they would use the two-period duopoly model to affect the shift of profit for two firms under a dumping situation. Again, like Brander and Spencer (1985) [12], they considered competition in quantities to analyze subsidy behavior on strategic trade policies. This paper extends the model of Knetter and Prusa (2003) [15] and Wang (2004) [17] to the case where firms compete in prices rather than in quantities. The model presented here is a two-stage game in which the home government sets the import tariff level in the first stage and firms choose a price level in relation to dumping in the second stage. Hence, sub-game perfection is the equilibrium concept employed. The equilibrium is solved by backward induction. Furthermore, dumping can be observed even if it does not increase the profit of the foreign firm: the foreign firm might commit not to dump to avoid punishment. According to relative analysis, an AD investigation will be filed when the domestic currency appreciates, which enlarges the dumping margin and make the domestic price and cost relatively expensive. In this way, it is easy to injury the domestic industry. It is also the reason why this area should be researched further.

\subsection{Optimal Import Tariff and Social Welfare without Antidumping Law}

The practice of international trade is complicated by the existence of different currencies. The offering price is the monetary factor in studying national economies in the international sphere. According to the definition of absolute purchasing power parity (PPP) ${ }^{1}$, the nominal exchange rate can be expressed as the relative value of prices between the two countries and is considered in equilibrium if there existsthe same "basket" of goods. Here, the nominal exchange rate is assumed to be $e=\frac{P}{P^{f}}$, which assumes the equality between the domestic price $P$, and the foreign price $P^{f}$, and it establishes a relationship between the exchange rate and the domestic price level. If an antidumping duty is not levied, the domestic and foreign firm's profit will become:

$$
\begin{gathered}
\pi_{t}\left(P_{t}, P_{t}^{f}\right)=P_{t} Q_{t}\left(P_{t}, P_{t}^{f}\right)-C Q_{t}\left(P_{t}, P_{t}^{f}\right) \\
\pi_{t}^{f}\left(P_{t}, P_{t}^{f}\right)=e_{t}\left\{P_{t}^{f} Q_{t}^{f}\left(P_{t}, P_{t}^{f}\right)-C^{f} Q_{t}^{f}\left(P_{t}, P_{t}^{f}\right)\right\}-\gamma_{t} X_{t}^{f}\left(P_{t}, P_{t}^{f}\right)
\end{gathered}
$$

Here, the domestic firm serves the home market with local production $\left(Q_{t}\right)$, while the foreign firm not only sells in its own market, but also exports to the host market from Webb's (1992) study. $X_{t}^{f}$ is the foreign export volume to the domestic country, and $X_{t}^{f}\left(=I M_{t}\right)=Q_{t}^{f}-Q_{t}$. Without the threat of $\mathrm{AD}$, the domestic and foreign firms only focus on maximizing their profits in each period. The production of goods from foreign firms exported to the domestic country threatens the domestic firm. According to Article 2 of the GATT/WTO Agreement, the sale of the like products destined for consumption in the domestic market of the exporting country should be considered homogenous and comparative in price. To avoid the "Bertrand paradox", imperfect substitutability is assumed in this section. Two countries originally use different levels of technology, transportation cost ...etc., so their cost functions are dissimilar, it means that the marginal $\operatorname{cost} C \neq e_{t} C^{f}$, but the marginal cost in each country is constant for the consideration of constant return to scale.

Taking the first order condition of the Equations (1) and (2), we obtain

$$
\begin{gathered}
\frac{\partial \pi_{t}}{\partial P_{t}}=Q_{t}+P_{t} \frac{\partial Q_{t}}{\partial P_{t}}-C \frac{\partial Q_{t}}{\partial P_{t}}=0 \\
\frac{\partial \pi_{t}^{f}}{\partial P_{t}^{f}}=e_{t}\left(Q_{t}^{f}+P_{t}^{f} \frac{\partial Q_{t}^{f}}{\partial P_{t}^{f}}-C^{f} \frac{\partial Q_{t}^{f}}{\partial P_{t}^{f}}\right)-\gamma_{t} \frac{\partial X_{t}^{f}}{\partial P_{t}^{f}}=0
\end{gathered}
$$

\footnotetext{
${ }^{1}$ Purchasing Power Parity (PPP) is a method that compares prices in different countries and adjusts the exchange rates until prices are on average the same in different countries. The PPP relationship implies that exchange rates can influence money market equilibrium through their connections to domestic and foreign prices.
} 
Since the second order conditions are satisfied as $\pi_{P P}<0, \pi_{P^{f} f^{f}}^{f}<0$.

If taking total differentials of Equations (1) and (2), we have

$$
\begin{gathered}
\pi_{P P} \mathrm{~d} P+\pi_{P P} \mathrm{~d} P^{f}+\pi_{P e} \mathrm{~d} e=0 \\
\pi_{P^{f} P}^{f} \mathrm{~d} P+\pi_{P^{f^{f} f}}^{f} \mathrm{~d} P^{f}+\pi_{P^{f} f^{f}}^{f} \mathrm{~d} e=0
\end{gathered}
$$

Since $\pi_{P e}=0, \pi_{P^{f} e}^{f}=\left(Q_{t}^{f}+P_{t}^{f} \frac{\partial Q_{t}^{f}}{\partial P_{t}^{f}}-C^{f} \frac{\partial Q_{t}^{f}}{\partial P_{t}^{f}}\right)<0^{2}$, so that the above equations can be rewritten in matrix form as:

$$
\left[\begin{array}{cc}
\pi_{P P} & \pi_{P P^{f}} \\
\pi_{P^{f} P}^{f} & \pi_{P^{f} f^{f}}^{f}
\end{array}\right]\left[\begin{array}{c}
\mathrm{d} P \\
\mathrm{~d} P^{f}
\end{array}\right]=\left[\begin{array}{c}
0 \\
-\pi_{P^{f}}^{f}
\end{array}\right] \mathrm{d} e
$$

where the determinant of the Jacobianmatrix $D=\pi_{P P} \pi_{P f_{P} f}^{f}-\pi_{P P} \pi_{P f_{P}}^{f}>0$, under the assumption of the Routh-Hurwitz stability condition ${ }^{3}$. By comparative static analysis, the reaction function of price with respect to the exchange rate can be expressed as follows:

$$
\begin{aligned}
& \frac{\mathrm{d} P}{\mathrm{~d} e}=\frac{\left|\begin{array}{cc}
\pi_{P P} & 0 \\
\pi_{P f_{P}}^{f} & -\pi_{P^{f} e}^{f}
\end{array}\right|}{D}=\frac{-\pi_{P P} \pi_{P^{f} e}^{f}}{D}<0 \\
& \frac{\mathrm{d} P^{f}}{\mathrm{~d} e}=\frac{\left|\begin{array}{cc}
0 & \pi_{P P^{f}} \\
-\pi_{P^{f}}^{f} & \pi_{P^{f} f}^{f}
\end{array}\right|}{D}=\frac{\pi_{P^{f} e}^{f} \pi_{P P^{f}}}{D}<0
\end{aligned}
$$

The above results represent the depreciation of the domestic currency ( $e$ increases) that makes the price value of the product go down. The depreciation of the exchange rate will also decrease the domestic and foreign prices. On the contrary, the appreciation of the domestic currency will increase the prices. This is expressed in Figure 1 which shows that the line $P P$ moves to $P^{\prime} P^{\prime}$ and determines the new equilibrium. The slope of $P P$ line is steeper than that of $P^{f} P^{f}$ line.

Under the appreciation situation, the exchange rate will make the domestic and foreign prices increase, and the margin of increasing domestic price is larger than that of the foreign price. If the foreign firm dumps its products onto the domestic market, it is easy to hurt the domestic industry. On the other hand, if the domestic currency depreciates, it is not easy for foreign firm to dump its products onto the domestic market, because the margin of decreasing domestic price is larger than that of foreign price. If it is still dumping under the depreciation situation, it would be in the LTFV (less than fair value) situation.

Compared to the results of Knetterand Prusa (2003) [15], if the elasticity of the foreign price with respect to the exchange rate is less than zero, the foreign firm will lower its domestic currency price. Their results also imply that when the domestic currency appreciates, the normal response of foreign firms is to increase the foreign currency price of shipments to the domestic market, but by less than the appreciation of the domestic currency. Increases in the price of shipments to the domestic market evidently reduce the chance that the foreign firm is guilty of LTFV pricing. It means that an overvalued domestic currency makes it less likely to find the foreign firm guilty of LTFV pricing. Moreover, Knetterand Prusa (2003) [15] also presented the price elasticity of demand, but did not consider the Marshall-Lerner condition, and hence obtain the different results. Empirically, within the international trade circumstance, it appears that most AD filings during the domestic currency appreciated. When the domestic currency appreciates, the foreign firm will increase its domestic sale price, but the increasing margin is smaller than that of domestic firm because when the domestic currency appreciates, it will increase costs such as marketing and transportation, and in turn raise the domestic price of the foreign firm.

\footnotetext{
${ }^{2}$ According to the equation (4), the F.O.C. is equal to zero, therefore $e_{t}\left(Q_{t}^{f}+\left(P_{t}^{f}-C^{f}\right) \frac{\partial Q_{t}^{f}}{\partial P_{t}^{f}}\right)=\gamma \frac{\partial X_{t}^{f}}{\partial P_{t}^{f}}<0$

${ }^{3}$ This is a stability condition. It means that own effects of price on marginal profit dominate cross effects. Referred from the Routh-Hurwitz condition for reaction function stability, if this condition holds globally, it implies global uniqueness of the equilibrium.
} 


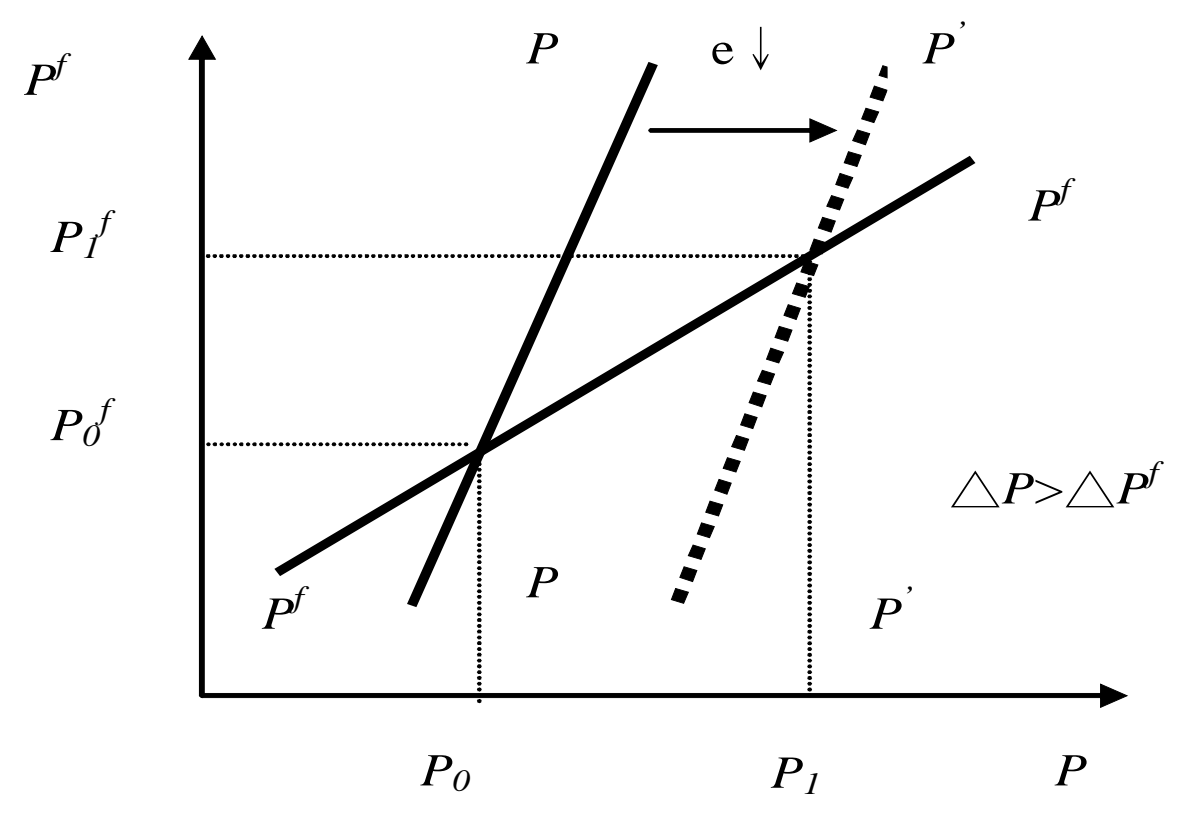

Figure 1. Appreciation of exchange rate increasing the price of the home and foreign goods.

This will contribute to an uncertain effect on AD filings due to the exchange rate fluctuations. In addition to trade and economic factors, political issues appear to have some importance in the model setups.

When home country levies tariff $\gamma$ on the imported products, it can get the extra benefits from the trade. The total measurement of domestic social welfare is the domestic firm's profit plus the tariff revenue. It can be presented by the following Equation (7).

$$
\begin{aligned}
\operatorname{Max} U & \equiv \pi_{t}\left(P_{t}, P_{t}^{f}, e_{t}\right)+\gamma X_{t}^{f}\left(P_{t}, P_{t}^{f}, e_{t}\right) \\
& =P_{t} Q_{t}\left(P_{t}, P_{t}^{f}, e_{t}\right)-C Q_{t}\left(P_{t}, P_{t}^{f}, e_{t}\right)+\gamma X_{t}^{f}\left(P_{t}, P_{t}^{f}, e_{t}\right)
\end{aligned}
$$

The optimal pricing strategy for the domestic firm is based on the government's consideration of the influence of the exchange rate. Under the best pricing condition, the first order condition of maximizing utility with respect to the local price using exchange rate exogenously is:

$$
\operatorname{Max} U_{\widehat{P}_{t}}=Q_{t}+\left(P_{t}-C_{t}\right) \frac{\partial Q_{t}}{\partial P_{t}}+\gamma_{t} \frac{\partial X_{t}^{f}}{\partial P_{t}}=0
$$

Therefore, the initial tariff rate would be obtained from the above Equation (8) and shown in Equation (9):

$$
\gamma_{0}=-\frac{\left|Q_{t}+\left(P_{t}-C_{t}\right) \frac{\partial Q_{t}}{\partial P_{t}}\right|}{\frac{\partial X_{t}^{f}}{\partial P_{t}}}=0
$$

Accordingly, free trade is the best policy for the domestic country if the exchange rate is exogenous. Owing to the fact that the exchange rate influence the trend of domestic and foreign prices, if the exchange rate is endogenous for price, the optimal reaction of maximization under the consideration of exchange rate is presented as follow:

\footnotetext{
${ }^{4}$ From the equation (3), it is clear that the result of $Q_{t}+\left(P_{t}-C_{t}\right) \frac{\partial Q_{t}}{\partial P_{t}}$ is equal to zero; moreover, $X_{t}^{f}=Q_{t}^{f}-Q_{t}$, and taking the differential with respect to the domestic price, the result will be positive, so that $\frac{\partial X_{t}^{f}}{\partial P_{t}}>0$.
} 


$$
U_{e_{t}}=\widehat{P_{t}}\left(\widehat{Q_{P_{t}}} \widehat{P_{e_{t}}}+\widehat{Q_{P_{t}^{f}}} \widehat{P_{e_{t}}^{f}}\right)+\widehat{P_{e_{t}}} Q-C\left(\widehat{Q_{P_{t}}} \widehat{P_{e_{t}}}+\widehat{Q_{P_{t}^{f}}} \widehat{P_{e_{t}}^{f}}\right)+\gamma_{t}\left(X_{\widehat{P_{t}}}^{f} \widehat{P_{e_{t}}}\right)=0
$$

From the equation (10), $\left(\widehat{P_{t}}-C\right)>0$ and $\left(\widehat{Q_{P_{t}}} \widehat{P_{e_{t}}}+\widehat{Q_{P_{t} f}} \widehat{P_{e_{t}}^{f}}\right)>0^{5}$, we know $\left(\widehat{P_{t}}-C\right)\left(\widehat{Q_{P_{t}}} \widehat{P_{e_{t}}}+\widehat{Q_{P_{t}}} \widehat{P_{e_{t}}^{f}}\right)=-\widehat{P_{e_{t}}} Q-\gamma_{t}\left(X_{\widehat{P}_{t}}^{f} \widehat{P_{t}}\right)$, i.e. the optimal tariff rate is

$$
\gamma=-\frac{\left(\widehat{P_{t}}-C\right)\left(\widehat{Q_{P_{t}}} \widehat{P_{e_{t}}}+\widehat{Q_{P_{t}^{f}}} \widehat{P_{e_{t}}^{f}}\right)+\widehat{P_{e_{t}}} Q}{\left(X_{P_{t}}^{f} \widehat{P_{e_{t}}}\right)}>0
$$

if $\gamma_{t}=0$, then $U_{e \mid \gamma_{t}=0}>0$. Therefore, if the home government levies a tariff on imported goods, it would increase the domestic social welfare.

Based on the above analysis, if the firms compete in prices and there is no antidumping law, the optimal policy for home government is to levy an import tariff. An import tariff decreases the after-tariff profit of the foreign firm. On the other hand, the domestic country will get extra benefits by levying an import tariff. It is a serious issue that the foreign firm does not want to be found guilty under dumping investigations. If it is found guilty, the foreign firm has to carry out the antidumping duty as a punishment, and this will decrease the foreign firm profit $^{7}$. Therefore, the foreign firm will use its influence on the domestic government to avoid the punishment of imposing an antidumping duty, such a threat of retaliation.

\subsection{Equilibrium Condition of Two-Period Analysis with Antidumping Law}

Here, a two-period duopoly model is applied to identify how the AD law is influenced by the foreign firm's pricing decision. Suppose there are two periods during the analysis, $t=1$, 2 . Without the threat of AD, the domestic and foreign firm simply maximizes their own profit in each period. The production of trade goods from foreign firm to overseas markets will threaten the local industry. Based on the Article 2 of GATT/WTO antidumping regulation, the firms sell the like products to the marketing places. To simplify the model, two firms (domestic and foreign) sell the like products and compete in price, and a two-period duopoly model for profit maximization and discounted by $\delta$ can be described as follows:

$$
\begin{gathered}
\operatorname{Max}_{\left\{P_{1}, P_{2}\right\}} \pi=\pi_{1}\left(P_{1}, P_{1}^{f}\right)+\delta \pi_{2}\left(P_{2}, P_{2}^{f}\right) \\
\operatorname{Max}_{\left\{P_{1}^{f}, P_{2}^{f}\right\}} \pi^{f}=\pi_{1}^{f}\left(P_{1}, P_{1}^{f}, e_{1}\right)+\delta \pi_{2}^{f}\left(P_{2}, P_{2}^{f}, e_{2}\right)
\end{gathered}
$$

When the domestic and foreign firms compete in price in the domestic market under the consideration of $\mathrm{AD}$ law, the foreign firm will be punished under the LTFV (less than fair value) and material injury determination. If the foreign firm sells in the domestic market at the LTFV price in the value of domestic currency during the first period, this means that the foreign price in domestic currency is less than the domestic price. LTFV sales can occur if $e_{1} P_{1}^{f}<\bar{P}$. Here, $\bar{P}$ is the benchmark price which turns out to be the same as whether calculated using the constructed-value or the price-based methods. The comparative price is independent of the exchange rate and $P$ is the price decided in the domestic market if there are constant marginal cost and non-imported goods.

Assume that both the domestic and foreign firms know the benchmark price $\bar{P}$, and that it is constructed by the general rules. If the distribution function $F($.$) is continuous and has been differentiated twice between$ $[0, \bar{P}]$, then the probability of LTFV will be defined as follows:

$$
\rho^{L}\left(P_{1}^{f}, e_{1}\right)=\operatorname{Prob}\left(e_{1} P_{1}^{f}<\bar{P}\right)=\int_{e_{1} P_{1}^{f}}^{\bar{P}} F^{\prime}(x) \mathrm{d} x
$$

\footnotetext{
${ }^{5}$ The direct domestic price effect with respect to the exchange rate dominates the indirect foreign price effect.

${ }^{6}\left(\widehat{P_{t}}-C\right)\left(\widehat{Q_{P_{i}}} \widehat{P_{e_{i}}}+\widehat{Q_{P_{i}^{\prime}}} \widehat{P_{e_{i}}^{\prime}}\right)+\widehat{P_{e_{i}}} Q>0$, and $\left(X_{\widehat{P}_{i}}^{t} \widehat{P_{e_{i}}}\right)<0$.

$\frac{\partial \pi_{t}^{f}}{\partial \gamma}=-X^{f}<0$
} 
The definition of injury, unless otherwise specified, shall be taken to mean material to a domestic industry, threat of material injury to a domestic industry or material retardation of the establishment of such an industry, and shall be interpreted in accordance with the provision of Article 3 in the GATT/WTO antidumping regulations. An injury determination will also be made before the AD duty is levied, when the domestic firm has been injured and if the after-injury profit is less than the normal profit. If the minimum profit under injury determination is $\pi^{I}$, and then the condition $\pi_{1}\left(P_{1}, P_{1}^{f}\right)<\pi^{I}+\eta$. According to Knetter and Prusa (2003) [15], a random component to the injury decision can be created by the influential factors beyond control, like political lobbying, global economic circulation...etc. Here, the injury distribution function $G(x)$ can be expressed under the assumption of common knowledge and zero mean. The probability of material injury occurrence is:

$$
\rho^{I}\left(P_{1}, P_{1}^{f}\right)=\operatorname{Prob}\left(\pi_{1}-\pi^{I}<\eta\right)=\int_{\pi_{1}-\pi^{I}}^{\infty} G^{\prime}(x) \mathrm{d} x
$$

The timing of playing the game is as follows: If the exchange rate is announced by the domestic government, it will determine the realization of first period prices, sales, and profits. Without $A D$ investigation and retaliation, the optimal trade policy for the home country is to impose an import tariff. When foreign import dumping occurs in the domestic market, and harms the domestic firm, the domestic government will initiate an AD investigation. Here, we assume that the domestic firm is a small-medium enterprise, which has not enough ability to investigate whether the foreign firm is dumping or not, and asks for the local government to practice this investigation. Based on the consideration of LTFV, material injury, retaliation and other situations, the government will announce the antidumping decision. If dumping is found to have taken place, consistent with the investigation under the GATT/WTO rules and national antidumping law, a dumping duty will be levied on the imported goods.

To solve the recursive model, the firms will understand that the duty has been levied to affect their pricing decisions. If an antidumping duty is not levied, both firms will maximize their profits as they did without AD law. On the other hand, if dumping behavior has been found, it turns that the dumping price is $P_{D}^{f}$, which is below the foreign market price, i.e. $P_{D}^{f}<P^{f}$. If dumping is not found to have occurred, the firms will set up their prices in the second period. Here, the dumping price will be consistent with the assumptions of dumping, relatively competitive advantage, material injury, and correspond to the condition of price differentials in Figure $1 P_{D}^{f}<P_{2}^{f}<P_{2}<P_{D}$. If home government announces the antidumping decision in period 2, the domestic firm will profit from the antidumping policy. The extra benefit for the domestic firm can be expressed as follows:

$$
\Psi\left(P_{D}, e_{2}\right)=\pi_{2}\left(P_{D}, P_{D}^{f}, e_{2}\right)-\pi_{2}\left(P_{2}, P_{2}^{f}, e_{2}\right)>0
$$

Moreover, if a dumping duty is levied on the foreign firm, the expected loss ofthe foreign firm can be presented as follows:

$$
\Gamma\left(P_{D}^{f}, e_{2}\right)=\pi_{2}^{f}\left(P_{D}, P_{D}^{f}, e_{2}\right)-\pi_{2}^{f}\left(P_{2}, P_{2}^{f}, e_{2}\right)-e_{2}\left(P_{D}^{f}-P_{2}^{f}\right) X_{2}^{f}\left(P_{D}, P_{D}^{f}, e_{2}\right)<0
$$

At the moment, it will be assumed that the domestic government finds it profitable for file an AD petition. Considering the LTFV and material injury situations, the two individual firms' expected profit function under the AD law situation will become:

$$
\begin{gathered}
\pi\left(P_{1}, P_{2}, P_{1}^{f}, P_{2}^{f}, P_{D}, P_{D}^{f}, e_{1}, e_{2}\right)=\pi_{1}(\bullet)+\delta\left\{\pi_{2}\left(P_{1}, P_{2}\right)+\rho^{L} \rho^{I} \Psi\left(P_{D}, e_{2}\right)\right\} \\
\pi^{f}\left(P_{1}, P_{2}, P_{1}^{f}, P_{2}^{f}, P_{D}, P_{D}^{f}, e_{1}, e_{2}\right)=\pi_{2}^{f}(\bullet)+\delta\left\{\pi_{2}^{f}\left(P_{1}^{f}, P_{2}^{f}\right)+\rho^{L} \rho^{I} \Gamma\left(P_{D}^{f}, e_{2}\right)\right\}
\end{gathered}
$$

Taking the first order condition of Firms' profit function with respect to the first period price, the result is obtained as follows:

$$
\begin{gathered}
\frac{\partial \pi(\bullet)}{\partial P_{1}}=\frac{\partial \pi_{1}}{\partial P_{1}}+\left\{\delta\left(1-\rho^{L} P^{I}\right) \frac{\partial \pi_{2}}{\partial P_{2}} \frac{\partial P_{2}}{\partial P_{1}}-\delta \rho^{L} P^{I} \frac{\partial \pi_{2}}{\partial P_{D}} \frac{\partial P_{D}}{\partial P_{1}}\right\}=0 \\
\frac{\partial \pi^{f}(\bullet)}{\partial P_{1}^{f}}=\frac{\partial \pi_{1}^{f}}{\partial P_{1}^{f}}+\left\{\delta\left(1-\rho^{L} P^{I}\right) \frac{\partial \pi_{2}^{f}}{\partial P_{2}^{f}} \frac{\partial P_{2}^{f}}{\partial P_{1}^{f}}+\delta \rho^{L} P^{I} \frac{\partial \pi_{2}^{f}}{\partial P_{D}^{f}} \frac{\partial P_{D}^{f}}{\partial P_{1}^{f}}-e_{2} \rho^{L} P^{I} \frac{\partial X_{2}^{f}}{\partial P_{1}^{f}}\right\}=0
\end{gathered}
$$

Under the dumping situation, the foreign firm adopts a dumping trade strategy in the second period to max- 
imize its profit by expanding the sales in the domestic market. According to the above analysis, dumping has obviously occurred during the period of domestic currency appreciated. Therefore, the appreciation pressure will push the domestic price increase to enlarge the dumping margin, and then the domestic firm will ask for an antidumping investigation and formally request home government to levy an antidumping duty.

In Equations (20) and (21), the first term in both equations can be interpreted as the marginal change to the first period profit, while the bracketed terms can be interpreted as the expression of net price change effects on the second period profit under the dumping situation. By contrast, as far as the foreign firm is concerned, the first period profit is not the only way of maximizing its eternal profit. Using dumping strategy is a tool of obtaining the future profit and crowds out the competitors in the sale market, so that the first period price has a direct impact on the LTFV and injury determination. In particular, the increase of the first period price will lower the probability of LTFV and injury, and reduce the second period loss.

As for the domestic government, antidumping determination will be decided by the consideration of antidumping law, industrial injury, and retaliation. When an antidumping duty is levied, the outcome is susceptible to national welfare effect in the second period. If the domestic government files an AD investigation and imposes an $\mathrm{AD}$ duty on the imported goods to maximize the social welfare, it will evaluate the effects of tariff revenue and retaliation loss. Retaliation might produce a tangible but invisible loss, which is the key evaluation for the domestic government when making an antidumping determination. Assuming that retaliation will have an impact on the domestic market demand, like shortage of import products; it will moreover increase unemployment due to increasing the wage rate and so on. Therefore, the two-period social welfare function will be decided as follows:

$$
\operatorname{Max}_{A D}=\pi_{1}(\bullet)+\delta\left\{\pi_{2}\left(P_{1}, P_{2}\right)+\rho^{L} \rho^{I} \Psi\left(P_{D}, e_{2}\right)\right\}+(\gamma+\tau) X_{2}^{f}-w\left(P_{D}, e_{2}\right) L-T C
$$

Here, $\tau$ is the antidumping duty, $w$ is the wage rate, $L$ is the loss of employment, and $T C$ is the cost of filing an AD investigation like retaliation or other loss (Bernhofen,1995) [10]. In order to see the effect of levying an $\mathrm{AD}$ duty, some of the exogenous variables, like wage rate, employment and others, are constant during the two periods. The domestic government will choose to file an $\mathrm{AD}$ investigation by using a benefit-cost analysis, and only considering the situation if

$$
\delta \rho^{L} \rho^{I} \Psi\left(P_{D}, e_{2}\right)+(\gamma+\tau) X_{2}^{f}-w\left(P_{D}, e_{2}\right) L-T C \geq 0
$$

This means that the expected payoff from filing an $\mathrm{AD}$ petition will not exceed the loss from investigation and retaliation. It is estimated that filing an AD investigation is positive to the likelihood of LTFV, injury and dumping margin. The exchange rate can be used as an indicator to reflect the price difference of the dumping margin and trade-off effects between $\rho^{I}, \rho^{L}$, while the dumping duty will be regarded as an exogenous variable in the model.

Based on Equation (20), the best pricing behavior for the domestic firm under the antidumping situation will be decided by maximizing the social welfare function.

$$
U_{\hat{P} \mid A D}=\frac{\partial \pi_{1}}{\partial P_{1}}+\left\{\delta\left(1-\rho^{L} P^{I}\right) \frac{\partial \pi_{2}}{\partial P_{2}} \frac{\partial P_{2}}{\partial P_{1}}-\delta \rho^{L} P^{I} \frac{\partial \pi_{2}}{\partial P_{D}} \frac{\partial P_{D}}{\partial P_{1}}\right\}+(\gamma+\tau) \frac{\partial X_{2}^{f}}{\partial P_{D}} \frac{\partial P_{D}}{\partial P_{1}}-\frac{\partial w}{\partial P_{D}} \frac{\partial P_{D}}{\partial P_{1}} L
$$

From the equation (19), we see that $\frac{\partial \pi_{1}}{\partial P_{1}}+\left\{\delta\left(1-\rho^{L} P^{I}\right) \frac{\partial \pi_{2}}{\partial P_{2}} \frac{\partial P_{2}}{\partial P_{1}}-\delta \rho^{L} P^{I} \frac{\partial \pi_{2}}{\partial P_{D}} \frac{\partial P_{D}}{\partial P_{1}}\right\}$ is equal to zero; there fore, the optimal tariff without considering the exchange rate will not occur, and the antidumping duty becomes

$$
\tau=\frac{\frac{\partial w}{\partial P_{D}} \frac{\partial P_{D}}{\partial P_{1}} L}{\frac{\partial X_{2}^{f}}{\partial P_{D}} \frac{\partial P_{D}}{\partial P_{1}}}
$$

Therefore, antidumping duty is strongly influenced by the wage rate, unemployment, and the amount of imported goods. If we take the exchange rate into account and reflect it in the prices to maximize the social utility

\footnotetext{
${ }^{8}$ See equation (9), the initial tariff is equal to zero.
} 
function, the optimal effect is

$$
U_{e \mid A D}=\widehat{\pi_{P_{1} e}}+\left\{\delta\left(1-\rho^{L} P^{I}\right) \frac{\partial \pi_{2}}{\partial P_{2}} \frac{\partial P_{2}}{\partial e}-\delta \rho^{L} P^{I} \frac{\partial \pi_{2}}{\partial P_{D}} \frac{\partial P_{D}}{\partial e}\right\}+(\gamma+\tau) \frac{\partial X_{2}^{f}}{\partial P_{D}} \frac{\partial P_{D}}{\partial e}-\frac{\partial w}{\partial P_{D}} \frac{\partial P_{D}}{\partial e} L
$$

Here, $\widehat{\pi_{R_{1}}}$ reflects the first period profit under the consideration of the exchange rate and determines the initial tariff rate $\gamma^{9}$. To estimate the antidumping duty, $\tau$ has to be calculated using the above equation. So,

$$
\tau=-\frac{\delta\left(1-\rho^{L} P^{I}\right) \frac{\partial \pi_{2}}{\partial P_{2}} \frac{\partial P_{2}}{\partial e}-\delta \rho^{L} P^{I} \frac{\partial \pi_{2}}{\partial P_{D}} \frac{\partial P_{D}}{\partial e}-\frac{\partial w}{\partial P_{D}} \frac{\partial P_{D}}{\partial e} L}{\frac{\partial X_{2}^{f}}{\partial P_{D}} \frac{\partial P_{D}}{\partial e}}
$$

Under this scenario, the extra tariff rate (which is equal to the antidumping duty) that the foreign firm has to pay for its export is determined by the home country's welfare. Comparing the result from the equation (26), we see that the outcome of such antidumping duty will be decided by the result of $\delta \rho^{L} P^{I} \frac{\partial \pi_{2}}{\partial P_{D}} \frac{\partial P_{D}}{\partial e}+\frac{\partial w}{\partial P_{D}} \frac{\partial P_{D}}{\partial e}$ (antidumping effect) and $\delta\left(1-\rho^{L} P^{I}\right) \frac{\partial \pi_{2}}{\partial P_{2}} \frac{\partial P_{2}}{\partial e}$ (normal effect). If the antidumping effect is greater than the normal effect, $\tau>0$, an antidumping duty will be levied on the imported goods. Otherwise, when the antidumping effect is smaller than the normal effect and $\tau<0$, the domestic government will decide not to punish the foreign firm, i.e. setting $\tau=0$, because it cannot satisfy the social utility maximization, and instead applies another trade protection policy like subsidizing the domestic firm, to reach the optimal state. The notion captures the initiation that the antidumping mechanism is to eliminate the price differentials. An antidumping duty is only imposed if the foreign firm charges a lower price abroad than in its home market, and is composed by the consideration of LTFV, industrial injury, and other economic variables, such as exchange rate, wages and employment. It is difficult to calculate the actual antidumping duty from the economic theoretical model, but it provides a platform for measuring the degree of antidumping occurrence.

\section{Concluding Remarks}

In imperfect competition, the duopoly model assumes that the exchange rate is exogenous, but it is endogenously determined in the real world to influence the variation of price level. The government has an incentive to administrate import tariffs when foreign firms are increasing their domestic market shares or levy antidumping duties when the foreign firms are growing too much due to selling at a lower price. Under the endogenous trade protection polic $y^{10}$, the market sale price will be determined by the impact of the exchange rate during the international trade situation. Moreover, the exchange rate will influence the sale price in the domestic and foreign markets. In this model, it is clearly seen that most of the dumping investigation will take place when the domestic currency is strong, because the appreciation will increase the price index and production cost in the domestic market. On the other hand, the foreign price relatively depreciates, leading to cheaper foreign imported goods. This study produces a result that is more reasonable than that derived by Knetter and Prusa (2003) [15], who found that the AD filing effects on foreign imported goods increased when currencies were weak. Their analysis also cannot explain the real phenomena because dumping behavior still exists in a currency overvalued situation and the domestic government also has the incentive to protect its own interests. Consequently, a dumping investigation will occur during the overvalue price situation.

Under the consideration of antidumping law and retaliation, the domestic government agency will evaluate the pros and cons to levy an $\mathrm{AD}$ duty. If it is worth filing an $\mathrm{AD}$ determination, the government agency will punish the foreign firm; if not, it will subsidize the domestic firm as the best policy of reaching maximization of utility. The dumping margin is a good indicator but difficult to determine for the investigation. Due to the fact that variations on economic variables can influence the price differentials, the government agency should not consider the dumping margin when determining the presence of material injury. The legislation points out that

\footnotetext{
${ }^{9}$ See the Equation (11), the initial tariff rate will be decided by the first period profit.

${ }^{10}$ Imperfect competition firms use their endogenous economic characteristics to influence the government trade policies.
} 
commissioners must determine whether material injury is caused by "the reason of dumped imports", rather than whether "the dumping per se causes injury".

Since most antidumping cases occur when there exists substantial intra-industry trade of the like products, the factors of price dumping and cost dumping were considered in this analysis. Moreover, an antidumping duty as a government choice protects domestic industries from unreasonable foreign competition. But it is very important for the domestic government agency to decide whether to levy an antidumping duty or not by comparing antidumping effects and normal effects under the consideration of national welfare. Now, for the future study we can extend this model to include all the industries for consideration of the economic environment, the total production for all industries will be reflected in GDP. Moreover, exchange rates, wage rates, price index, unemployment rates, exports and imports are good indicators for analyzing the antidumping petition.

\section{References}

[1] Matschke, X. and A. Schöttner (2009) Antidumping as Strategic Trade Policy under Asymmetric Information. Working paper, No.2008-19, Department of Economics, University of Connecticut, USA.

[2] Pierce, J.R. (2011) Plant-Level Responses to Antidumping Duties: Evidence from US Manufacturers. Journal of International Economics, 85, 222-233. http://dx.doi.org/10.1016/j.jinteco.2011.07.006

[3] Viner, J. (1966) Dumping: A Problem in International Trade. Augustus M. Kelley, N.Y.

[4] Herander, M.G. and Schwartz, B.J. (1984) An Empirical Test of the Impact of the Threat of US Trade Policy: The Case of Antidumping Duties. Southern Economic Journal, 51, 59-79. http://dx.doi.org/10.2307/1058322

[5] Hartigan, J.C. (1995) Collusive Aspects of Cost Revelation through Antidumping Complaints. Journal of International and Theoretical Economics, 151, 478-489.

[6] Ethier, W.J. (1982) Dumping. Journal of Political Economy, 90, 487-506. http://dx.doi.org/10.1086/261071

[7] Hillman, A.L. and Katz, E. (1986) Domestic Uncertainty and Foreign Dumping. Canadian Journal of Economics, 19, 403-416. http://dx.doi.org/10.2307/135339

[8] Dixit, A.K. (1988) Anti-dumping and Countervailing Duties under Oligopoly. European Economic Review, 32, 55-68. http://dx.doi.org/10.1016/0014-2921(88)90034-7

[9] Brander, J.A. and Krugaman, P.R. (1983) A “Reciprocal Dumping” Model of International Trade. Journal of International Economics, 15, 313-323. http://dx.doi.org/10.1016/S0022-1996(83)80008-7

[10] Bernhofen, D.M. (1995) Price Dumping in Intermediate Good Markets. Journal of International Economics, 39, 159173. http://dx.doi.org/10.1016/0022-1996(94)01357-X

[11] Webb, M. (1992) The Ambiguous Consequences of Anti-Dumping Laws. Economic Inquiry, 30, 437-448. http://dx.doi.org/10.1111/j.1465-7295.1992.tb01973.x

[12] Brander, J.A. and Spencer, B.J. (1985) Tariff Protection and Imperfect Competition. In: Kierzkowski, H. Ed., Monopolistic Competition and International Trade, 194-206, Clarendon Press, Oxford.

[13] Bian, J. and Gaudet, G. (1997) Anti-dumping Laws and Oligopolistic Trade. Journal of Economic Integration, 12, 6286. http://dx.doi.org/10.11130/jei.1997.12.1.62

[14] Wares, W.A. (1977) The Theory of Dumping and American Commercial Policy. D.C. Heath and Company, Lexington.

[15] Knetter, M.M. and Prusa, T.J. (2003) Macroeconomic Factors and Antidumping Filings: Evidence from Four Countries. Journal of International Economics, 61, 1-17. http://dx.doi.org/10.1016/S0022-1996(02)00080-6

[16] Goldberg, P.K. and Knetter, M.M. (1997) Goods Price and Exchange Rate: What Have We Learned? Journal of Economics Literature, 35, 1243-1272.

[17] Wang. T.K. (2004) Foreign Lobbying, Competitive Behavior and Strategic Trade Policy. Journal of International Business and Economics, 8, 251-261.

[18] Marsh, S.J. (1998) Creating Barriers for Foreign Competitors: A Study of the Impact of Antidumping Action on the Performance of U.S. Firms. Strategic Management Journal, 19, 25-37. http://dx.doi.org/10.1002/(SICI)1097-0266(199801)19:1<25::AID-SMJ926>3.0.CO;2-C

[19] Konings, J. and Vandenbussche, H. (2002) Does Antidumping Protection Raise Market Power? Evidence from Firm-Level Data. CEPR Discussion Paper, No. 3571.

[20] Blonigen, B.A. and Haynes, S.E. (2002) Antidumping Investigations and the Pass-Through of Antidumping Duties and Exchange Rates. The American Economic Review, 92, 1044-1061. http://dx.doi.org/10.1257/00028280260344597

[21] Kelly, B.D. (2010) Antidumping Investigations and the Pass-Through of Antidumping Duties and Exchange Rates: Comment. The American Economic Review, 100, 1280-1282. http://dx.doi.org/10.1257/aer.100.3.1280 
[22] Blonigen, B.A. and Haynes, S.E. (2010) Antidumping Investigations and the Pass-Through of Antidumping Duties and Exchange Rates: Reply. The American Economic Review, 100, 1283-1284. http://dx.doi.org/10.1257/aer.100.3.1283

[23] Deardorff, A.V. (1987) Safeguards Policy and the Conservative Social Welfare Function. In: Kierzkowski, H., Ed., Protection and Competition in International Trade, Basil Blackwell, Oxford, 22-40.

[24] Deardorff, A.V. (1989) Economic Perspectives on Antidumping Law. In: Jackson, J.H. and Vermulst, E.A., Eds., Antidumping Law and Practice, Harvester Wheatsheaf, New York, 23-39. 